\title{
Clément Juglar and his contemporaries on the causes of commercial crises
}

Daniele Besomi

\section{(2) OpenEdition}

\section{Journals}

Electronic version

URL: http://journals.openedition.org/ress/110

DOI: 10.4000/ress. 110

ISSN: 1663-4446

\section{Publisher}

Librairie Droz

\section{Printed version}

Date of publication: 1 March 2009

Number of pages: 17-47

ISBN: 978-2-600-01275-1

ISSN: 0048-8046

\section{Electronic reference}

Daniele Besomi, «Clément Juglar and his contemporaries on the causes of commercial crises », Revue européenne des sciences sociales [Online], XLVII-143 | 2009, Online since 01 March 2012,

connection on 19 April 2019. URL : http://journals.openedition.org/ress/110 ; DOI : 10.4000/ress.110 


\title{
Daniele BESOMI*
}

\section{CLÉMENT JUGLAR AND HIS CONTEMPORARIES ON THE CAUSES OF COMMERCIAL CRISES}

\begin{abstract}
On this question, various and contradictory opinions have been formed; and if the notorious fact of the public distress has united the sentiments of all parties on this single point, they seem to differ as widely as ever in their judgments as to the causes of it.
\end{abstract}

[Anonymous, 1816, p. 375]

\section{INTRODUCTION: OF CONTINENTS AND ISLANDS}

Until recently, the writings of Clément Juglar had not been much read or cited first hand ${ }^{1}$ (hopefully this issue will contribute to stimulate interest in his work). His name, however, frequently recurs as a qualifier of the «Juglar cycle», and his fame largely rests upon Joseph Schumpeter's well-known appreciation. Schumpeter elevated Juglar to the status of founding father of business cycle theory, on the ground of his early usage of time-series, of his attribution of the cause of crises to the preceding prosperities, and to his characterization of the morphology and of the periodicity of crises. Schumpeter recognised that some of these topics were touched upon by other writers before Juglar, but he described him as the discoverer of the continent while his predecessors had only hit on some of the islands near it (Schumpeter 1954, pp. 1123-4).

Schumpeter's story is based on a less than careful exploration of both the continent and the islands. On the one hand, his account is based not on the first edition of Juglar's book on Des Crises Commerciales et de leur Retour Périodique en France, en Angleterre et aux Etats-Unis, published in 1862, but on the second one, published in 1889. Schumpeter, however, projected Juglar's 1889 achievement back to 1862 (actually, to 1860, as Schumpeter quotes the wrong publication year). But the two books are rather different in a number of substantial aspects, and on some of the newly introduced issues much had been written by Juglar's contemporaries in the intervening three decades.

On the other hand, the pre-Jugarian literature on crises is much richer than Schumpeter suspected. Many of the issues discussed by Juglar had been

Address for correspondence: daniele.besomi@unil.ch.

1 Obvious and welcome exceptions are Niehans 1992, Pellissier 2000, Groenewegen 2001, and Frobert and Hamouda 2005, all focussed on Juglar, who is also referred to in some histories of econometrics (some passages are cited below). 
thoroughly examined by a number of writers before him. A more careful assessment of Juglar's position in the (far from linear) development of crises and cycles theories is therefore overdue. This paper aims at providing some elements towards a reconstruction of the theoretical context in which Juglar's theory was elaborated. This should not be intended as a hunt for Juglar's forerunners. Although almost all of the ideas he expressed can be found in some form somewhere in the literature a few decades earlier, ideas only make sense in their context, and apparently similar ideas taken in isolation may not prove fecund of further illumination. What matters here is the feeling of general awareness of the issues related to crises discussed by Juglar, and the widespread diffusion of the ingredients of he used to build his theory.

The resulting survey is unavoidably partial, because of the very nature of the materials at hand. Most writings were housed in pamphlets, ephemera and articles in commercial, financial or general purpose journals which today are not easy to retrieve, and only very rarely in books or articles in professional journals (in part because professional journals were rare at the time, in part because, as Schumpeter observed, «not much to their credit, the scientific leaders of the profession were not conspicuous» among the participants in the debates on crises (1954, p. 742)). The landscape to be described is made up of writers of different sorts from lawyers to merchants, politicians to financiers, lawyers to historians, and occasionally economists as well - fiercely debating the causes of crises and their possible remedies. This will therefore be more the story of a set of problems than an account of the answers (although in some cases the answers were formulated without full awareness of the generality of the problem). The picture that emerges is that Juglar was not alone in taking up some of the above-mentioned problems, while he left untackled other important issues his contemporaries were instead discussing.

The story is thus more complicated than what can be read from Schumpeter's passages on Juglar taken in isolation. It features many characters, only partially aware of the net of interrelated components necessary to produce a consistent theory of the cycle but each working (some partially consciously, Juglar among them, some fully without awareness) towards the gradual euthanasia of crises and glorification of cycles.

The paper is structured as follows: in part I, the main components of Juglar's view of the cycle are singled out, beginning from his early writings and with his more mature work (in separate sections, as the changes were in places rather drastic). The timing is important, for in the almost three decades between Juglar's two editions, numerous contributions on the subject were published. Part II examines the state of the debate before and at Juglar's time with respect to the recurrence and concatenation of phases, causation, the relationship of growth and crises, the use of statistics, the ingredients of Juglar's analytical construction, the implications of the usage of medical metaphors, and the relationship of crises to equilibrium. The closing section draws some conclusions. 


\section{PART I. JUGLAR'S VIEWS ON PERIODICAL CRISES}

\section{I.1. Laying out the premises}

Juglar's argument, as developed in a long article on «Des Crises Commerciales et Monétaires de 1800 à 1857» in the Journal des Economistes (Juglar 1857), in more detail in the first edition of Des Crises Commerciales et de leur Retour Périodique en France, en Angleterre et aux Etats-Unis (1862), and taken up in the entry on "Commercial crises" for Block's Dictionnaire général de la politique (1863), is simple enough. Historically, commercial crises (crises commerciales) are always accompanied by monetary crises (crises monétaires). Juglar thus analysed long series of banking statistics (discounts, metallic reserves, circulation of banknotes, deposits), at first only for France (1857) and later also for England, the United States and to a lesser extent, for Prussia and Hamburg (1862), which he compared with the variations in population ${ }^{2}$, the price of corn, import and exports, rents and public revenue. He noted a strict correlation (especially in the variations of discounts and reserves) and that changes go through specific phases, always the same, and are in concordance in the countries where commerce and industry are more developed. From this regularity, Juglar inferred ${ }^{3}$ that the common premise to all crises lies in the excesses of speculation and in the inconsiderate expansion of industry and trade (1857, p. 36, and 1862, pp. 6 and 164). The exuberance of speculation and enterprise is rooted in human nature (1857, p. 37, and 1862, p. 7), liable to become overexcited (1857, p. 37) and to fall prey of the passion for gamble (1862, pp. 205-6) during the prosperous phase of activity, when «tout paraît conspirer pour donner un essor sans pareil aux affaires; toutes les entreprises qui se fondent trouvent les capitaux nécessaires; on s'arrache les titres, on les achète avec une confiance sans réserve dans l'avenir» (1862, pp. 6-7; 1857, p. 36). Expenditure can, for a time, exceed receipts only thanks to credit $(1862$, p. 164). Excesses are thus nothing else than abuse of credit $(1862 \text {, pp. } 34,38)^{4}$. But this cannot last: a crisis will intervene, bad credits and other excesses will be liquidated, the system is brought back to its normal course of development which it will be able to follow for a few years, before new abuses again shatter its foundations.

The theoretical apparatus is admittedly scanty: as Juglar himself pointed out in the second edition of his book, looking back at his original statement, the «loi des crises et de leur périodicité» was derived «sans faire intervenir aucune théorie, aucune hypothèse », but by way of «l'observation seule des faits » $(1889, \mathrm{p} . \mathrm{Xv})^{5}$.

2 In 1852, Juglar wrote an article on population in France from 1725 to 1849. In the introduction to his book, Juglar indicates that after having recorded the influence of epidemics, wars and famines, he wanted to examine how the state of trade affects population dynamics (1862, pp. i-ii). A short chapter of the book is dedicated to this problem.

3 Rather unwarrantedly: see footnote 21.

4 At this point, however, Juglar's emphasis is fully on speculation (see e.g. 1862, p. 199); credit will conquer the center of the stage in the second edition of Juglar's book, where the explanatory mechanism will be considerably amplified and centered on the relationship of credit, prices and speculation. See below, section I.2.

5 Niehans stresses that in Juglar «very little economic analysis» is to be found (1992, p. 549). 
Moreover, he was also wary of generalizations that could be drawn from his observations as to the cause of crises: "Quoique l'examen des documents statistiques qui vont suivre puisse engager à conclure et à reconnaître une loi économique, la prudence conseille de ne pas trop se hâter» $(1862$, p. 6). Juglar's purpose, indeed, was not the development of an analysis of the causes of crises, but stressing that these follow a common path and are related to each other:

Le renouvellement et la succession des mêmes faits, dans des circonstances spéciales, dans tous les temps, dans tous les pays et sous tous les régimes, voilà ce qu'il fallait faire remarquer (1862, p. xiii).

Juglar's book was an answer (indeed, the winning answer) to a competition launched by the «Académie des Sciences Morales et Politiques » in 1860, challenging the entrants to

Inquire into the causes, and indicate the effects, of commercial crises ${ }^{6}$ that took place in Europe and North America during the XIX Century. These crises have been frequent at any epoch; but, as commercial relations have expanded, the perturbations crises bring with are also touching more and more regions (Académie des Sciences Morales et Politiques, 1860).

Juglar's approach consisted in relying on large numbers and long periods rather than on disputable assertions (Juglar 1862, p. xiii). It was a precise methodological choice, which he pursued at the price of producing a tedious book:

La répétition constante des mêmes accidents donne une monotonie réelle à notre histoire: nous sommes forcés de passer successivement et toujours par les mêmes phases, non sans causer un certain ennui à l'esprit qui aime la variété et toujours avide de nouveautés; n'est-ce pas cependant la meilleure confirmation de ce que nous voulions démontrer? $(1862, \text { p. xii })^{7}$

Methodology and rhetoric are better married in the following stage of Juglar's argument. If crises are not to be taken as disconnected individual occurrences but have some features in common and tend to recur cyclically, there must be a common explanation of the phenomenon, in spite of the different circumstances affecting different economic systems at different times. In most of the literature of the time, however, crises were attributed to a number of different causes. Juglar was aware that he had to play two games at the same time if he wanted to win his case. On the one hand, he had to encompass all crises under the same scheme in spite of the objective differences between each special occurrence by reinterpreting the role of the special events and of the general premises of crises. On the other hand, he had to counter all his opponents' arguments at once.

Juglar handled this challenge very effectively. The first edition of his book began with a discussion of the term "cause" ${ }^{8}$. Juglar took up the distinction, rooted

6 The plural should be noted. As it will be argued below (section II.2), the idea that crises recur and are part and parcel of capitalistic development was already widely shared at the time of Juglar's first writings on the subject.

7 «A proof by boredom!» (Morgan 1990, p. 41).

8 The passages cited in these paragraphs also appeared in the second edition, but as the second chapter (1889, pp. 27-29). 
in the medical reflection of the time, between 'causes déterminantes' and 'prédisposition'. As he only explained and exemplified the second term $(1862$, p. 2), but not the first (which he used on p. 1), it is expedient to refer to the entry on 'causes' in the Dictionnaire de Médicine Usuelle, published only three years after Juglar completed his medical dissertation on the influence of heart diseases on the lungs:

\begin{abstract}
Nous nous bornerons donc aux divisions principales ou à la classification des causes morbides. Il en est qui préparent les maladies; elles sont pour la plupart dans l'organisation elle-même: on les nomme prédisposantes; d'autres, presque toutes extérieures, font éclater la prédisposition et produisent la maladie, et l'on appelle celles-là déterminantes ou occasionnelles. Prenons un exemple: cet homme a le cœur volumineux, le sang abondant, le cou court, cette complexion est la cause prédisposante à l'apoplexie; que, maintenant, dans un accès de colère, il soit foudroyé, l'émotion sera la cause occasionnelle. Sans la prédisposition, les influences maladives sont impuissantes, mais les signes qui la révèlent sont souvent cachés. Ce ne serait pas une mince difficulté que d'annoncer $a$ priori quelle serait la part de chacun de quatre imprudents qui, couchés en sueur sur de la terre humide, devraient se relever l'un avec un rhumatisme, l'autre avec un catarrhe pulmonaire, le troisième avec une diarrhée, le quatrième en santé parfaite. L'examen préalable de l'organisation de chacun aiderait sans doute à la solution du problème, mais avant l'épreuve le résultat resterait souvent incertain. (Lagasquie 1849, p. 313)
\end{abstract}

Without mentioning crises (thus remaining at the level of general principles of explanation), Juglar pointed out that when we look for the «causes déterminantes» of what surrounds us we are «under siege by a crowd of occasional causes » that «impair our view and often induce us to mistake the accident for the very origin of the affliction»(Juglar 1862, p. 1). The following passage is a rhetorical masterpiece, as it expounds the principle that will subvert the adversaries' approach while at the same time very subtly ridiculing them:

Le véritable critérium des causes, c'est de les voir, dans des circonstances semblables,
reproduire les mêmes effets, particularité malheureusement assez rare dans les phéno-
mènes sociaux et dans tout ce qui touche à la vie. Dans cette incertitude, on invoque tour
à tour les causes les plus contraires pour se rendre compte des mêmes effets. On est
surpris de la légèreté, de la facilité avec laquelle l'esprit humain accepte tout ce qu'on lui
propose; tellement il est avide de savoir, de se rendre compte, et, quand il ne trouve rien
de mieux, combien facilement il se paye de mots. La multiplicité même des causes que
l'on invoque le plus souvent suffit, il nous semble, pour prouver leur peu d'efficacité,
puisque, alors qu'une seule devrait suffire, on en accumule un grand nombre, sorte que,
comme elles ne sont pas toujours réunies pour produire le même effet, on peut aussi
rigoureusement, conclure, en les éliminant une à une, qu'aucune n'est cause détermi-
nante, pas même secondaire, puisque sa présence n'est pas indispensable pour produire
le résultat attendu. (Juglar 1862, p. 2)

Juglar concluded that one should study the «état antérieur [...] en l'absence duquel les causes que l'on croirait les plus puissantes sont sans action. C'est ce qu'en médecine on appelle la prédisposition » (ibid.). Accordingly, when we pass to crises (which in Juglar's argument only appears at this point), we have to identify «les conditions indispensables à leur existence, sur les phénomènes constants que l'on observe alors en dehors des causes si diverses, si variées, que l'on invoque selon le besoin du moment» (p. 3) ${ }^{9}$. Juglar could thus successfully

9 Groenewegen (2001, pp. 122-3) emphasised the medical origin of Juglar's notion of predisposition and caught well its meaning and implication without, however, remarking that the concept was 
contrast his unifying perspective to his opponents' special views, and indeed he took every chance to do so (for instance 1862, iii, ix-xi, 1-2, 5-6, and passim; he further insisted on this in the second edition of his book, 1889, pp. 5;27-29, 36, $43,165,197)$.

Juglar's emphasis on the predisposing causes has two consequences. One, is that in the absence of predisposition, a cause that could bring havoc would instead be ineffective (1862, p. 2). During prosperity, when people are overexcited, « une grande guerre ne saurait arrêter le mouvement» $(1857$, p. 57). The second is that the actual determining causes are not that relevant, as the crisis would have happened anyway. When everything is predisposed for the crisis any accidental cause would precipitate it, like the last drop overflowing a full glass of water (1862, p. v). «Les mauvaises récoltes, la cherté des céréales, les disettes, par leur retour périodique se rencontrent assez souvent dans notre pays avec l'engorgement du portefeuille des banques, et apportent une nouvelle complication à une situation déjà mauvaise: leur présence n'est cependant pas indispensable pour produire une crise commerciale» $\left.{ }^{\mathrm{p}} \mathrm{x} . \mathrm{x}\right)^{10}$. These causes are thus reinterpreted as explaining not the actual crisis, but its specific character. The interpretation of crises as individual events, each with its own specific cause, is thus turned on its head: the occasional circumstance only determines the specificity of each crisis, the difference with other similar events, while the general pattern is determined by the way in which the predisposing cause determines the unstable state of the system at certain points.

Two aspects deserve to be stressed in this connection. The first regards the notion of 'periodicity'. If accidental circumstances affect the actual course of crises, they can make them more or less intense but also anticipate or retard them. In Juglar's view there is no room for strict periodicity ${ }^{11}$. The adjective 'periodic' occurring in the title of Juglar's book thus refers to a different conception, which (not surprisingly) again happens to be more akin to the medical than to the astronomical one ${ }^{12}$. The emphasis is not much on the period ${ }^{13}$, but on the return of the various phases which succeed each other in precisely the same order with similar characteristics. The notion is thus related to cyclicity in general terms, to the idea

counterposed to the 'determining cause', which also plays a part in the methodology and the rhetoric of Juglar's construction. Frobert and Hamouda, in their otherwise interesting essay on the medical metaphor in Juglar, altogether failed to take up the point (Frobert and Hamouda 2005).

${ }^{10}$ Juglar went so far as claiming that wars and revolutions are actually a consequence, not a cause of crises: 1857,$38 ; 1889$, p. xvii

${ }^{11}$ In truth he did not insist on this point in the first edition, but he specifically tackled it in the second: see section I.2.

${ }^{12}$ Beaude's Dictionnaire de Médicine Usuelle, 1849, p. 621: «Période: se dit des différentes phases d'une maladie; une période suppose un certain nombre de jours pendant lequel s'est accomplie une des révolutions de la maladie». Accordingly Juglar attached the term 'période' to the denomination of the prosperous phase ('période prospère': 1862, p. 164) and later also to the phase of liquidation ('période de liquidation' (1900, p. 9). See for instance the Dictionnaire de l'Académie Française, 6th and 7th editions (1835 and 1878, respectively) for a comparison of the different intensions of the substantive.

13 Juglar, however, indicates the approximate average length of the cycle: the crisis is sudden and short, liquidation takes 1-2 years, prosperity about 6-7 years $(1862,202)$. 
that crises are not disconnected individual occurrences but part of a chain of events implying the return of disturbances after some conditions are fulfilled, rather than to the specific kind of cycles that repeat themselves with strict regularity.

Juglar identified three phases: prosperity, crisis, and liquidation (1862, p. 164), and discussed how they succeed each other. The presentation, as well as the cycle itself, is asymmetric. The focus is on crises: their origin, their nature, their outbreak, their liquidation. As anticipated early in this section, during prosperity people become unduly optimistic (1862, pp. 202, 205-6) and start overspeculating. The keywords, recurring in a long string, are 'imprudence', 'abuses', 'excesses': «il est dans la nature humaine de ne se tenir jamais dans des justes limites» (p. 20) and become overexcited (167). The result is «excès de spéculation » $(16,20,24,88)$, «extravagante application du capital flottant» $(25$, reporting Wilson's opinion on the 1847 crisis), «écarts de la spéculation» $(6,164,199)$, «spéculation insensée» $(25)$ or «imprudente», $(142,208)$ «aux déla de leurs moyens » (142), «développement exagéré des escomptes » $(27,31,209)$, «abus du crédit» $(29,34,38,88)$, «overtrading » $(29)$, «crédit fictif » $(34)$, «douteux » (172) or «artificiel» $(57,163)$, «prix exagéré » (37), « développement inconsidéré de l'industrie» $(164)^{14}$. Some of these exaggerations and excesses refer to the credit market and the stock exchange, others affect production and goods markets. In particular, expenditure exceeds receipts, and investment runs ahead of saving: among the results of the excess of speculation there is «souvent aussi l'emploi et l'immobilisation d'un capital supérieur à celui qui pouvait fournir les ressources ordinaires du pays, autrement dit l'épargne» (164; see also 38 and 154).

So far as it goes, such a situation remains in an increasingly insecure balance: «tant que la hausse persiste, on échange les produits, personne ne perd, mais malheur au dernier détenteur !» (1862, p. 14). As speculation is carried on, tension accumulates $^{15}$, and the system becomes extremely unstable. While in the earlies stage of prosperity the system could remain unaffected even by a war (1857, p. 57), towards the end it becomes like a basin about to overflow $(1862$, p. v) or like explosive ready to blast $(1862$, p. $176 ; 1863$, p. 8$)$, so that any occasional cause can set it off leading to «perturbations sérieuses pour des causes peu graves» $(1862, \mathrm{v})$. Juglar describes the failure of the system by means of the hydraulic metaphor of pipes becoming engorged: «tout à coup tous les canaux paraissent remplis, il n'y a plus d'écoulement possible, toute circulation cesse et une crise éclate. Toutes les spéculations s'arrêtent; l'argent, si abondant quelque mois auparavent, diminue, se resserre, disparaît même» (1857, p. 37).

How can these pipes be unblocked? The system must get rid of the unhealthy speculation, and here the medical man emerges again. Commercial crises, «comme dans les maladies [...] préparent un état meilleur en rejetant au dehors

${ }^{14}$ All citations are from the first edition of Juglar's book (1862); the list could easily be extended with a number of similar citations from other of his writings, such as 1863 , p. 8 ; similar quotes from the second edition and other late writings are given in section I.2.

15 «Un crédit trop tendu que les charges accumulées finissent par rompre» (1862, p. 176). Niehans thus considers Juglar's conception as belonging to the family of relaxation oscillation theories of fluctuations (1992, p. 546-7). 
tout ce qui était impur» $(1862$, p. $14 ; 1863$, p. 8$)$. The diseased parts have to be suppressed (208): during the liquidation the less solid businesses fail «et débarrassent le marché d'une cause incessante de trouble et de ruine» (14; see also 208). Eventually the system is brought back to its healthy, normal state (1863, p. 8$)^{16}$, a stable $(1862$, p. 208) equilibrium (pp. v, 172): « une crise n'est qu'une liquidation générale pour permettre aux affaires de reprendre sur un base plus solide» (176).

From these passages Juglar's conception of the nature of capitalist accumulation emerges rather clearly. Prosperity is the normal state of the system, and consists in the «développement régulier de la richesse des nations » ${ }^{17}$. In its early stages this is a self-sustaining state of moving equilibrium, where one's expenditure covers someone else's costs. Credit is a necessary premise to the increasing number of exchanges and therefore to accumulation; at this junction it does not create any problems, for everybody is confident that it can be liquidated easily. Yet the instinct for gambling brings to overspeculation, which is by its nature cumulative: credits become more and more doubtful, and at some point the system turns extremely unstable. The crisis explodes: excesses and abuses are wiped out, and the system is reconducted back to its normal track. In this view, periodical crises are a necessary inconvenience: they are «un dérangement dans la marche des affaires » $(1863$, p. 1$)$, but a disturbance intrinsic ${ }^{18}$ to the accumulation process, and actually helpful, for economic advance contains and develops the germs of growing instability which have to be cleared. The resulting crisis is conceived as the undesirable product of accumulation itself, and the premise for its recovery:

\begin{abstract}
les crises, comme les maladies, paraissent une des conditions de l'existence des sociétés où le commerce et l'industrie dominent ${ }^{19}$. On peut les prévoir, les adoucir, s'en préserver jusqu'à un certain point, faciliter la reprise des affaires; mais les supprimer, c'est ce qui jusqu'à ici, malgré les combinaisons les plus diverses, n'a été donné à personne. Proposer un remède à notre tour, quand nous reconnaissons le peu d'efficacité de ceux des autres, n'était pas possible, d'autant que leur évolution naturelle rétablit l'équilibre et prépare un sol ferme sur lequel on peut s'appuyer sans crainte pour parcourir une nouvelle période. (1862, p. vii).
\end{abstract}

${ }^{16}$ Santé: «Etat dans lequel toutes les fonctions s'exécutent librement et facilement: c'est l'état normal» (Beaude's Dictionnaire de Médicine Usuelle, 1849).

17 Wolowsky 1860 , citing the «mémoire» submitted by Juglar to the Académie in 1860; in Juglar 1862, p. xiv.

${ }^{18}$ Intrinsic; not, as stated by Frobert and Hamouda (2005), 'normal'. Juglar reserved the term 'normal' to prosperity, the equilibrium state free of the exaggerations of credit and speculation (the passages relating to the first edition are given in the text, while the references to the later writings will be given below, section I.2), and indeed there is nothing normal in a diseased organism. The normality of the entire cycle is an issue that arose later (see Besomi 2006, pp. 72-79). Frobert, and Hamouda (2005) however, have rightly stressed that Juglar's analogy of crisis as illness was rooted in the medical conception of his time, which saw illness as part of the physiology of an organism. Their argument that this metaphor has played a heuristic role in the development of Juglar's thought, rather than a purely illustrative one, is of considerable interest.

${ }^{19}$ Juglar is adamant - it is also part of his rhetorical apparatus - that the periodicity of crises is a universal and synchronous phenomenon (1862, for instance pp. 4, 13, 15 and passim), but only relative to countries where commerce, industry, and especially credit are developed (e.g. p. 5). 
Although the endogenous/exogenous distinction was conceptually well within Juglar's reach, for it is strongly implied in the distinction between determining cause and prédisposition (as witnessed by the dictionary entry cited above), he did not make that step. This apparently curious situation is due to the povery of his theoretical and analytical apparatus: the concepts of endogenos and exogenous refer to internal and external with respect of the theoretical system, but Juglar's line is so ill-defined that an analytical classification would not be possible. A first problem in this respect, which Juglar tackled in the second edition, is that the mechanism declenching the crisis is not clear. Intuitively, one grasps that the instability increases as speculation proceeds, so that at some point anything can act as the occasional cause. But the specific mechanisms explaining how instability grows are absent: the explanation relies on the public's «élan» (201), «fureur» (205), «engouement, frénésie» (202) in subscribing to any new enterprise ${ }^{20}$. At this point of Juglar's analysis, the society's disease is thus explained by individual madness.

The second problem is more troublesome. The 'normal state' is not defined. Prosperity is said to be an equilibrium, a state of regular progression supporting itself, but it is not clear how this happens; its driving force is never specified, nor are its equilibrium conditions. A notion uniquely based on the absence of 'abuses' and 'exaggerations' is, of course, circular reasoning. The tendency to accumulate thus remains unexplained, and so is the lower turning point: it is not enough to say that bad credits are liquidated and excesses eliminated if what drives the recovery is not specified. This has obvious implications on the exogenous/endogenous distinction: if the endogenous forces driving growth are not specified, one cannot define by contrast what is exogenous.

But there is also an implication regarding the conception of the cycle. Juglar hints that phases do not simply follow each other in a regular fashion, but that each one breeds the following: prosperity brings the germ of disorder (1862, p. 121; see also 172), the crisis is by necessity followed by a liquidation. In both directions, « une fois le mouvement commencé dans un sens ou dans l'autre, croissant ou décroissant, il continue sans interruption jusqu'au moment où un revirement complet a lieu». The point is precisely that one needs to explain the «revirement »; but in Juglar's book how prosperity gives rise to crisis is only intuitively clear, while is is fully unclear how and why liquidation gives place to prosperity ${ }^{21}$. A full explanation of the cycle is still wanting, but Juglar can offer a description («nous voudrions montrer ici qu'on peut en suivre le développement pas à pas, presque mois par mois, au moins, d'une manière très claire, année par année»: 1862, p. 164), even a diagnostic (pp. 197-8); but at any rate, he laid out the principle that an explanation of a cyclical process requires that phases are linked to each other.

\footnotetext{
${ }^{20}$ One may also note that the passage cited at the opening on this section, where Juglar 'prit son parti' and inferred from the regularity of the recurrence of crises that at its origin there must be excesses of speculation, was left unexplained. If he identified the culprit before starting his inquiry, the latter was bound to bring precisely that result !

${ }^{21}$ There is an asymmetry here, which reflects in the asymmetry in the division in three phases: while what happens during the prosperity provides the 'cause prédisposante' of the crisis, liquidation prepares the way for the recovery (this appropriate wording is suggested by Hutchison 1953, p. 371) which, however, does not need a specific cause, it is just in the nature of things.
} 


\section{I.2. Revising, adding, and deepening}

The second edition of Des Crises Commerciales was published in 1889. It is almost three times as long as the first edition, obviously containing many new materials, in particular further statistics (Juglar brought up to date his previous series, to confirm and give more strength to his results: $1889, \mathrm{p} . \mathrm{xv}$ ), additional considerations on the lines already expounded in the first edition, and a shift of emphasis in the argument giving more weight to the role of prices in Juglar's mechanism.

Juglar insisted more than he did before on some significant points in the transition from crises to cycle theories. The most interesting one concerns the linkage between phases ${ }^{22}$. While in the first edition, the emphasis was on the succession of phases in the same relative order, in the new version Juglar stressed the chaining of phases; in the first edition the approach was more descriptive, in the second Juglar more clearly aimed at developing a causal explanation. It is no longer enough to record that «les périodes s'enchaînent, se suivent avec une régularité qui étonne toujours» (pp. 9, 48, 164). One must move a further step: «ces trois périodes reconnues, il fallait chercher les rapports qu'elles pouvaient avoir entre elles et sous l'influence de quelles causes elles se succédaient» (pp. 21; 4), it is necessary to understand how each phase results from «la réaction qui se succède à l'action» (p. xvi).

The basic idea as to how each phase is characterized remained the same, although the connection between phases now worked via changes in the price level ${ }^{23}$. Prosperity, at least in its early stages, is a stable equilibrium of advance, the system's normal, healthy state. As opposed to crisis as a diseased condition ${ }^{24}$, «Dans le langage vulgaire, la période prospère n'a pas de nom; c'est ce que l'on regarde comme l'état normal, on n'en parle même pas; il en est de la prospérité

${ }^{22}$ Although the book is still centred, also terminologically, on crises, the terms «circle» (p. 10) and «cycle» (pp. 17, 97, 162, 166, 554 - the list is due to Niehans 1992, p. 550) are occasionally used. The term - and some similar ones, such as 'fluctuations', 'waves' - has been in use long since: some instances are cited in Section II.2.

${ }^{23}$ In Niehans's view, Juglar's focus on prices - as well as that of most of the literature on cycles up to the interwar years, when prices were substituted by output - reflects the fact that statistics were more readily available (1992, p. 552). This explanation, however, fails to account for the shift of emphasis between the first and second edition: some statistics on prices were available by 1862 (in particular those collected by Tooke), but Juglar choose instead to inquire into banking data, in spite of the difficulties in gathering some of them. The reference to prices as a link between credit and speculation enabled Juglar to give a better formulation of the cumulative process in the upswing, and gives some intuitive kind of characterization of the prosperity phase in terms of equilibrium in prices (not a static one, but an equilibrium of raising prices reflecting the joint acceleration of credit and production), which was entirely lacking in the first edition. One may thus conjecture (pending historical research into the development of Juglar's thought) that Juglar was aware that his first edition lacked an adequate theoretical basis and that his intuition needed a more precise analytical setup. He would have easily found the missing ingredient in the literature of the time: see section II.4.

${ }^{24}$ The medical metaphor also reappears in other of Juglar's late writings: «La crise commerciale, comme dans les maladies, est un moment critique à passer» (1900a, p. 641); les crises «ne sont pas des accidents, un malaise fortuit impossible à prévoir, mais bien une véritable maladie parfaitement déterminée, qui survient à époques presque fixes et qui annonce toujours son arrivée » (Juglar and Des Essars 1989, p. 1355). 
comme la santé, rien ne paraît plus naturel» (p. 16): «c'est l'état normal du marché, la période prospère » (p. 33). It is characterised by an equilibrium in prices (p. xvi) which is only broken when credit gets out of hand (pp. 53-54) ${ }^{25}$. Credit itself is necessary to permit growth and thus prosperity ${ }^{26}$. Yet its 'exaggerated extension' and 'abuse' (pp. 5, 47, 56, 168) 27 $^{27}$ to pay for 'excessive expenses' (p. 4) is driven by the 'gambling attitude' of the public (p. 4) fed by the price increases generated by these same expenses, in a speculation spiral eventually destabilising the system ${ }^{28}$. This happens when purchases are no longer in proportion with the available capital (p. 53): «l'équilibre des prix est rompu» (pp. 54, $34,35,165)^{29}$. Juglar resorted again to the analogies of the loaded explosive charge (pp. 30, 43, 165; see also 1900a, p. 646) and the overfull water basin (pp. 48, 165), that can explode or, respectively, overflow, due to any occasional cause, to stress the methodological point that the 'predisposition' to crises lies at a deeper level than the accidental or determining causes (see also 1889, p. 197).

Although «le mot crise indique un état de malaise ou de souffrance» (p. 13), Juglar repeats (citing Overstone) that crises imply «des inconvénients sous quelques rapports », but are «à d'autres points de vue extrêmement salutaires et avantageuses » (p. 6): they are useful, and indeed a necessary premise to the beginning of the recovery (p. 6), for they eliminate the excesses and bring the system back to equilibrium. Contrary to the first edition, now Juglar offers a mechanism triggering the recovery: during the liquidation phase no investments are taking place. Some savings, however, are still coming forward seeking productive use and lowering the interest rate until the «esprit d'entreprise» is awakened again ${ }^{30}$. When there is request of capital, credit intervenes again, and the cycle can recommence. The explanation, however, still relies on the 'esprit

${ }^{25}$ This (as we already had in the first edition: see section I.1) is occasionally expressed in terms of a comparison of the public's habits as to savings and the use of capital, as mediated by credit (p. xix).

26 «La prospérité d'une nation dépend du développement des affaires, et [...] il n'y a pas d'affaires sans crédit» (Juglar 1889, p. 48).

${ }^{27}$ On the abuses of credit as cause of crises see also Juglar 1900, p. 10.

28 Juglar used the expression «l'équilibre instable du marché» or «du crédit», with reference to the last phase of the prosperity when speculation prevails (1889, pp. 34, 165). Emphasis on instability recurs in several of Juglar's writings : crises «éclatent d'abord sur une place quand la situation est déjà très tendue, ébranlent et renversent cet équilibre instable, s'étendent sur tout le monde des affaires, puis se liquident dans les mêmes conditions pour reparaître après avoir parcouru le même cycle» (1882, p. 5). «Cette prospérité repose sur une base essentiellement fragile» (Juglar and Des Essars 1889, p. 1349)

${ }^{29}$ Juglar stresses that credit permits increasing demand, and thereby leads to raising prices. It is clear, however, that he is not referring to consumers' credits, but to credits for prodution. Yet Juglar does not seem to account for the increase in production this should entail, which should to some extent compensate for the increase in demand. Tugan-Baranowsky actually criticises Juglar for not having realised that if demand increases, so does supply: he inverts Juglar's perspective, asserting that it is not demand preceding supply, but the other way around (1913, pp. 243-4).

${ }^{30}$ Juglar 1889 , pp. $21,30-31,126$. It may be noted that this mechanism is similar to the one later propounded by Tugan-Baranowsky (see Besomi 2006a), although Tugan himself found it «très maladroit» (1913, p. 243). A mechanism based on the cumulation of loanable funds during depression, however, was meanwhile expounded by Bagehot (1873, pp. 149-50). 
d'entreprise', on the 'natural' (and unexplained) tendency to accumulate ${ }^{31}$; the accumulation of loanable funds only plays a subsidiary role ${ }^{32}$.

It should be noted that Juglar is more concerned with credit by traders rather than by banks, in the form of promises to pay (p. 57, 69, 71, 73); not only the request for such credit grows with increasing prices, but also the traders' willingness to accept promises as a form of payment, and both in turn further increase prices $^{33}$. Having shifted the emphasis on prices, Juglar supplied a new definition of crisis: " la crise serait donc l'arrêt de la hausse des prix, c'est-à-dire le moment ou l'on ne trouve plus de nouveaux preneurs» (p. 14) ${ }^{34}$.

An interesting feature of the second edition lies in the continuous confrontation with the doctrines of other authors on crises. This inaugurates a tradition that continues today, with many treatises on cycles expounding, for critical or contextualization purposes, the competing or the similar approaches.

On the second edition as compared to the first, Niehans commented that «the content was finally living up to the title », providing a massive treatise on business cycles while the previous version was just «a detailed chronicle of crises as reflected in bank balance sheets, with a few fragmentary statistics from other sources and very little economic analysis»(1992, pp. 549-50). The above summary suggests that this judgment does less than justice to the first edition. Already in the first version there was a description (albeit intuitive only) of the mechanism of crises resulting from the gradually increasing tension due to the abuses of credit triggered by speculation. The crisis would be followed by liquidation, setting the premises for a new recovery thanks to the elimination of the previous excesses. Niehans perhaps credits too much to the second edition, where the mechanism of expansion is still dependent on an unexplained tendency to accumulate. At any rate, the second edition did something to fill the gap of the missing explanation of the trough of the cycle, thus providing a more satisfactory account of the complete process.

31 The point is also stressed by Niehans (1992, pp. 553-5) and by Bergmann (1895, pp. 256-7). Hutchison listed Juglar among the workers in the field of crises and cycles «sceptical or ignorant » of the theoretical developments in the analysis of normal equilibrium of prices, value, production and distribution (1953, p. 425).

${ }^{32}$ It is an asymmetrical role: while Juglar mentions (without, in truth, insisting particularly on the point) the role of the accumulation of unused capital during liquidation, he explicitly denies that scarcity of capital at the end of prosperity may play a role in causing the crisis (p. 138).

${ }^{33}$ This account of Juglar's revised edition is far from complete. His description of the credit mechanism, including its international implication on specie and other transactions, is completely ignored here as not relevant for the topic of this essay. For a summary see e.g. Niehans 1992, pp. 555-8.

${ }^{34}$ After having stressed that prosperity is characterized by rising prices, that the crisis approaches when the increase slows down, and finally bursts out when the movement ceases altogether, in a dangerous passage Juglar adds: «En un mot, la principale, on pourrait dire l'unique cause des crises, c'est l'arrêt de la hausse des prix» (p. 33). Having defined crisis as the moment of stoppage of the raise of prices, Juglar is running in circles (thereby giving room to the criticism of Tugan-Baranowsky 1913, pp. 241-4, and Minnie England 1913, p. 346), and is laying the premises for eliminating the now redundant notion of crisis altogether. He did not, however, take such a step (which came about two decades later at the hand of another Frenchman, Lescure (1907), who suggested that crisis be the name of the upper turning point 


\title{
PART II. CRISES AND CYCLES AT JUGLAR'S TIME
}

Historical inquiries have already stressed that some of Juglar's proposition were not only anticipated by others but were even commonplace. Other aspects, however, have not yet been the subject of research. My aim is not to hunt for Juglar's forerunners, but to gather enough evidence on the diffusion, at his time, of a number of the ingredients that later were to constitute the core of his business cycle approach. Although this cannot claim to be a complete reconstruction of the context in which Juglar was operating (because it strictly remains within the field of the construction of economic theories of cycles and crises, leaving out for instance the political component of the debate - which would deserve a dedicated study - and its social implications), this step is necessary in order to assess the place of his contribution as a whole in the history of the transition from crises theories to cycle theories.

\section{II.1. Statistics}

One of the most distinctive features of Juglar's work is the extensive use of historical and statistical analysis in connection with the cycle. Of this, there was only a precedent: Tooke's chronicle of prices (1823, 1838-57). Malthus commented that in the pursuit of his

\begin{abstract}
inquiry into the causes of the fluctuations which have occurred during the last thirty years in the prices of corn and other commodities, [Tooke] adduces a large and interesting collection of facts. This mode of considering his subject we consider as peculiarly judicious. At all times an extensive collection of facts relative to the interchange of the various commodities of the commercial world, which is more within the reach of intelligent merchants than any other class of men, cannot but be of great importance to the science of political economy; but it is more particularly required at the present moment, when it must be acknowledged that some of our ablest writers in this science have been deficient in that constant reference to facts and experience, on which alone it can be safely founded, or further improved» (Anonymous [Malthus], 1826, p. 214)
\end{abstract}

'Collections of facts' were indeed produced. Morier Evans published in 1859 a massive analysis of the 1857-58 crisis, which he compared to those having occurred from 1825. His volume includes a number of data of various kinds, especially balance sheets but also banking statistics, numbers of stores and of failures, prices, stocks, debts, production, etc., enabling him to observe that «Each separate panic has had its own distinctive features, but all have resembled each other in occurring immediately after a period of apparent prosperity, the hollowness of which it has exposed», and even to stress that the uniformity is so striking that whenever fortunes can be rapidly accumulated «otherwise than by the road of plodding industry » one can safely predict that a panic is at hand $(1859, \text { p. } 1)^{35}$. Max Wirth also produced a voluminous (over 470 pages, almost twice as much as Juglar's first edition) body of historical analysis of crises, beginning from the consequences of John Law' system in France. Although peppered with data, the

${ }^{35}$ Evans's book counts over 200 pages of text and 250 pages of appendices, mainly consisting in balance sheets. 
nature of this work is historical, rather than statistical. On top of these volumes, a number of authors cite brief series of data or (more rarely) draw diagrams (e.g., Langton 1857).

These contributions, however, were scarcely useful. As Niehans stressed, Tooke's data were assembled more as a chronicle rather than with a theoretical purpose. As to Evans's data, they needed to be further distilled if anything had to be done with them.

In this context, Juglar's data marked some progress, as they were subject to some statistical analysis (rudimentary as it was $^{36}$ ) that could actually support some inductive process. In this, Juglar was soon followed by Jevons (who, being a far better statistician, was more influential than Juglar), and later Tugan, Bouniatian, Aftalion, Lescure, Robertson, and finally Mitchell (whose inductivist approach and specific statistical methodology to some extent resembles Juglar's: Niehans 1992, pp. 552-3 and Pellissier 2000, p. 275), to cite only the main contributors.

\section{II.2. Periodicity, or the return of crises}

Early recognitions of some regularity in the occurrence of crises, attempts to evaluate an average period, and the distinction of phases and their concatenation have been well studied in the literature. Juglar indeed appears in the first systematic study of the theories of crises, by Eugen von Bergmann, in the chapter on periodicity (1895, pp. 255-60).

The first identification of a cycle in production (albeit agricultural) seems to be due to William Petty, exactly two centuries before the publication of Juglar's book:

Suppose a man could with his own hands plant a certain scope of Land with Corn, that is, could Digg, or Plough, Harrow, Weed, Reap, carry home, Thresh, and Winnow so much as the Husbandry of this Land requires; and had withal Seed wherewith to sow the same, I say, that when this man has subducted his seed out of the proceed of his Harvest, and also what himself hath both eaten and given to others in exchange for Clothes and other Natural necessaries; that the Remainder of Corn is the natural and true Rent of the Land for that year; and that the medium of seven years, or rather of so many years as makes up the Cycle, within which Dearths and Plenties make their revolution, doth give the ordinary Rent of the Land in Corn (Petty 1662, cap. IV, §13, p. 43 Hull edition).

Although this may not seem relevant in the context of industrial fluctuations, one must remember that a number of authors later took agricultural production as the starting point of their reflections (Briaune (1840), for instance, but also numerous French scholars at the time of Juglar's writing $\left.{ }^{37}\right)$. Indeed, this passage is doubly scored in Jevon's copy of Petty's book (Foxwell 1884, p. 361).

We may jump to the 1820 s, remembering, however, that a number of authors in between reflected on the misfortunes of commerce and the havoc brought by

${ }^{36}$ On Juglar's statistical method see Pellissier 2000, pp. 274-6.

${ }^{37}$ On the 1847 crisis, among French authors see e.g. De Molinari (1847, p. 274) and Horace Say - who pointed out that «chacun le reconnaît» that crises had origin in the scarcity of crops (1847, p. 194). For a nice sample of authors attributing the main cause of the 1857 crisis to the agricultural factors (Lavergne, Bénard, Hippolite Dussard) see the proceedings of the meeting of 5 December 1857 of the Société d'Economie Politique. 
speculative movements. In 1823, Thomas Tooke wrote of 'waves' ${ }^{38}$ in prices, which however were attributed mainly to exogenous events: bad seasons, by causing price increases, encourage the development of credit which in turn feeds back on prices ${ }^{39}$. Later, in his History of Prices Tooke also incorporated endogenous elements, describing some phases (crises, in particular) as a reaction to the previous development ${ }^{40}$. By the end of the $1820 \mathrm{~s}$, descriptions of the alternation of prosperities, with rising prices and speculation, and depressions accompanied by falling prices, were already commonplace (Miller 1927, p. $193^{41}$ ). At this time we find the first attempts to estimate the period: an anonymous American reported in 1829 that «an opinion is entertained by many » that the average period of these «fluctuations» (the term is used several times) that «do take place, and [...] always will take place in countries, where paper money has been extensively introduced» is about 14 years. In 1833, John Wade estimated that «The commercial cycle is ordinarily completed in five or seven years, within which terms it will be found, by reference to our commercial history during the last seventy years, alternate periods of prosperity and depression been experienced $\gg^{42}$. In 1838 , Hyde Clarke was under the impression that cycles (this is the term he used), in nature and society, are subject to an elementary mathematical law (Clarke 1838; without, however, specific reference to economic cycles); he considered not only 10 -years cycles, but also 54-years long waves, yet he did not actually publish these reflections until 1847 (see Collison Black 1992, Henderson 1992, and for early appreciations Jevons 1878 and Bergmann 1895, p. 239). Briaune, in a 1840 pamphlet on Des crises commerciales. De leurs causes et de leurs remèdes (note the word in the plural) explicitly wrote about the "périodicité des crises commerciales » (p. 2), referring only to their return, without any reference to a more or less strict period. In 1848, Coquelin wrote that 'commercial perturbations' " have become in

38 The oceanic metaphor frequently reappears in connection with cycles, for instance in Langton: «These disturbances [quarterly and seasonal fluctuations] are the accompaniment of another wave, which appears to have a decennial period, and in the generation of which, moral causes have no doubt an important share» (1858, p. 11). Mills, who cites Langton approvingly, specifies: «They are indeed 'waves', as distinguished from the current or tide» (1868, p. 13). Other early occurrences are cited by Miller: a speaker in the Massachussets House of Representatives attributed to «periodical revulsions, «occurring «about every three years» «as much regularity as the billow from the ocean (Rantoul 1836, p. 14); Balfour commented on the «apparently tidal regularity » with which crises recur (1848, p. 477).

39 Tooke 1823, Part I, section VII: «Explanation of the causes of extension and contraction of private paper and credit». For a discussion see Arnon 1991, pp. 74-7.

${ }^{40}$ Tooke 1838-57. For a discussion see Link 1959, pp. 127-147; for Schumpeter's appreciation of the endogenous character of Tooke's account see 1954, pp. 744-5. Precisely for this reason, Spiethoff considered Tooke as Juglar's predecessor: in Persons's summary, «Juglar's forerunner, says Spiethoff, was not Sismondi, Malthus, J.-B. Say, or Marx, but Thomas Tooke (1774-1858). In support of this view, Spiethoff says that Tooke (1) used expressions for commercial expansion, crisis, and depression, (2) placed these phenomena in the nineteenth century, describing their features, and (3) pointed out their cyclical character» (Spiethoff 1925, p. 61, cited in Persons 1926, p. 98).

${ }^{41}$ On the theories of crises in France among socialist writers (including some maintaining that they recur cyclically) see Marcy 1946.

42 Wade 1833 , p. 211. On Wade's theory of the cycle, including a previous version of 1826 (probably the first fully endogenous models) see Besomi 2008. 
certain countries in some degree periodical» (Coquelin 1848, cited from the 1850 translation, p. 219; and Coquelin 1852, p. 528); Lawson wrote that examining the English panics «we shall find these periods of commercial distress regularly and periodically recurring in cycles of from five to seven years ${ }^{43}$. Within a couple of decades, most writers agreed on a period of about seven to eleven years, culminating of course in Jevons' claim that the phenomenon is strictly periodical ${ }^{44}$. «Crises» and «panics» began to appear, in the plural, in the titles of articles and pamphlets (see for instance Chitti 1839, Briaune 1840, Coquelin 1848 - where he also added that panics recur almost periodically; the passage is taken up by Mills 1867, p. $14 \mathrm{n}$, adding that the following 20 years enable to suppress Coquelin's 'presque' -, 1849 and 1850, Société d'Economie Politique 1857, Clément 1858, Bonnet 1859; Lawson 1848, Joplin 1854), and some histories of crises were published (Bell 1850; Members of the New York Press 1857; Wirth 1858; Evans 1859).

As a certain frequency and regularity in the occurrence of crises was acknowledged, commentators started to recognise some common pattern: by the end of the 1850 s it was common to agree that, in spite of the differences, crises resemble each other in that they recur after periods of prosperity. Some authors went further, and attempted a characterization of the phases of the cycle. Lord Overstone's list of 10 phases is often cited:

The history of what we are in the habit of calling the 'state of trade' is an instructive lesson. We find it subject to various conditions which are periodically returning; it revolves apparently in an established cycle. First, we find it in a state of quiescence, next improvement, - growing confidence, - prosperity, - excitement, - overtrading, convulsion, - pressure, - stagnation, - distress, - ending again in quiescence. (Overstone 1837 , p. 31)

This account is quite illustrative of the «circular course» through which trade progresses, but Overstone did not even attempt to give these phases an analytical content. More suggestive is Longfield's representation in 10 phases of the «fluctuations of trade »: a detailed description of the banks' discounts and their effects upon trade is illustrated with the ten phases (caution, confidence, liveliness, overtrading, great apparent prosperity, sudden cessation, paralysis, distrust, panic, bankruptcies) written in a circle, the period of which is said to be about five years. The account is not only descriptive: each stage of the process, although not easily encompassed to a specific phase in the list, witnessing the lack of analytical precision, is described in detail as following consequentially from the preceding one (Longfield 1840, pp. 222-3). Briaune boiled down the number of phases to three ( «crise», « reprise des affaires ${ }^{45}$, «dévelopement commercial»), but like Over-

${ }^{43}$ Lawson 1848, p. 2. Lawson added, anticipating Juglar, the observation that crises « are diseases which exhibit themselves only in a very civilized state of society, where trade and commerce flourish, where there is commercial enterprise and spirit; they occur in England, France, Holland, and the United States of America; but I do not find any account of such in Spain or Portugal».

${ }^{44}$ Summaries of the main positions are given in Jevons (1878) 1884, pp. 222-4, and Miller 1927 , pp. 192-3. The most detailed account is Bergmann's (1895, pp. 235-60).

${ }^{45}$ Such a division, in contrast to Juglar's, stresses the revival rather than the liquidation. The ingredients for a four-phases synthesis were thus already present. 
stone he only used them in a descriptive way, without trying to specify an analytical content (1840, p. 13).

Without referring to an elaborate classification of phases, James Wilson (1839) also propounded a semi-endogenous explanation of the alternation of high and low prices of agricultural products, in terms of a cobweb-like concatenation of states: low prices of agricultural products discourage production; the less fertile fields are abandoned, and after some time production actually diminishes. This determines a price rise, which induces to cultivate again the less fertile fields, and after a lag production increases ${ }^{46}$. The mechanism is not entirely endogenous as it is fed by the false expectations in prices created by changes in the Corn Laws. Later Wilson also suggested that these fluctuations extend to the whole productive system (1840; see Link 1956, pp. 103-26).

Seen in the context of these contributions, it is apparent that Juglar's emphasis on the succession of crises rather than on their singularity did not constitute a novelty, but was rather the product of the atmosphere of his time. True, the writers cited above are exceptions rather than the rule ${ }^{47}$, as most commentators, «in America as elsewhere, regarded a commercial crisis, not as a phase of a business cycle, but as the unhappy interruption of a normal trend of business that might have continued indefinitely had it not been for the unfortunate circumstances that brought on its collapse. Their observation of the cycle centered upon its most conspicuous phase - the crisis. Accordingly, the first attempts to explain crises sought the origin of each in some particular incident of the time. No general explanation common to all crises was offered; some writers explicitly denied that one could be formulated» (Miller 1927, p. 187) ${ }^{48}$. But not only commentators were

46 A similar mechanism was suggested by McCulloch in 1826, to explain the fall of prices of corn for 1804 and 1812-13: «high prices [...] attracted so much additional capital to the land, and occasioned such an extension of tillage, that we grew [...] an adequate supply of corn for our own consumption. And it is certain, that, under such circumstances, the price of corn must inevitably have fallen » (in 1814 as a consequence of an abundant crop, in 1804 simply as a consequence of the application of new capital). McCulloch brings as «uniform and striking» evidence the fluctuations in the number of enclosure acts (Anonymous 1826, pp. 72-3).

${ }^{47}$ A nice example of disparate causes of crises advocated by Juglar's learned colleagues at the time he was beginning to write is the summary of a discussion having taken place in December 1857 at the Société d'Economie Politique: «M. Ch. Renouard, conseiller à la Court de Cassation, résume les principales causes de la crise: dans la disette, première cause indépendante des hommes; - dans la guerre, qui a occasionné des pertes directes et indirectes et jeté le trouble dans l'économie sociale; dans le développement excessif des travaux publics; - dans l'esprit de spéculation qui, de sa nature, tend à aller toujours à l'extrême ; - dans la situation morale du pays, qui abandonnant beaucoup trop, il faut le dire, les nobles préoccupations des arts, des sciences, de la politique, des grandes idées, enfin, s'est beaucoup trop exclusivement jeté dans les préoccupations d'affaires, de jouissance physique et de luxe» (Société d'Économie Politique 1857, p. 473).

${ }^{48}$ As the leading example of the attitude of those who rejected the possibility of finding a unifying explanation, Miller cites Roscher. An anonymous 'Political economist' writing to the editor of the Economist against the «Alleged commercial decades or cycles» (1864) indicates that such an interpretation was widespread. However, when the Commissioner of Labor inquired into into the causes of depressions, his agents reported, along with some of the usual suspects, also a number of extravagant ones, such as the abolition of the apprentice system, the reckless legislation in Congress, depressions and mental diseases, too much and indiscriminate education, immorality, extravagant living. In his Geschichte der Nationalökonomischen Krisentheorieen (1895) Bergmann collected and classified in 
increasingly aware that crises (or panics) come in 'waves', but started to look for a unifying explanation, one that tells of a coherent story of phases succeeding each other in the same order. The 10-phases classifications were certainly too clumsy, and Juglar's three phases not only provided a welcome simplification and a morphological description closer to what was later found useful (Scumpeter 1954, p. 1124), but gave (or, rather, attempted to give) an analytical specification to each phase. But by 1862 Juglar had only indicated that he intended to show how phases succeed one another; one of these transitions, however, was still left hanging in the air, and the other was only hinted at.

\title{
II.3. Credit, speculation, psychology, prices
}

All the analytical ingredients used by Juglar to explain how prosperities build up the premises to crises had been extensively advocated before him, albeit in different combinations. While the explanations Juglar rejected, based on mismanagement of the currency or on specificities of the banking system, were quite popular at the time (as witnessed by the debate between currency and banking schools, which echoed well beyond England), credit was one of the favorite culprits for a number of writers (and an accomplice even in the view of most participants in the debates on currency and banking). As aptly summarized by Miller in his study on banking theories in the U.S. before 1860:

\begin{abstract}
Credit was believed to play a threefold part in producing crises. First, it enabled men to 'overtrade' in periods where mutual confidence was high. Secondly, it formed a network of interrelations through which the insolvency of a few merchants embarrassed a great many others. [...] Finally, some emphasized the fact that the use of credit instruments in normal times furnishes a substitute for money, so that, when in troublous times cash payments are insisted upon in lieu of credit formerly extended, the financial stringency becomes all the more acute (Miller 1927, pp. 189-90).
\end{abstract}

Miller supplies a number of references from American writers (to which Walker, in a discussion with Homer Stansfield, should be added: 1860), but it would be easy to list writers from other countries who held similar views (for instance Garnier 1845, Coquelin 1852, 1852a, Société d'Economie Politique 1854, Courcelle-Seneuil 1858, Rey 1862, Bonnet 1865 for France; Tooke 1823, Pt I, section VII, Langton 1857, Williams 1858, MacLeod 1863, p. 626 - with his emphasis on «misused credit [as] the cause of those terrible mercantile catastrophes which periodically sweep over the world »- for England, Ferrara 1864 for Italy]

Strictly related to credit are speculation and the psychology of the public, which were also often (but not exclusively) advocated in connection with credit. Credit permits speculation beyond one's own means, and manias feed the process. Psychology was also called to play a part in the reversal of the movement, as indicated by the very word 'panic' used to indicate (and also characterize) the financial aspect of crises. Here again a few examples will suffice: Lawson cites a 1825

eight categories 230 different opinions on the origin and nature of crises (these were counted by Lescure: 1907 , p. 13 - who, however, in a later edition revised the total to 280 -; also quoted by Robertson, 1915, p. 1). A further list of extravagant opinions is given by Wells 1889 (1899 ed., pp. 20-6). 
writer who described the causes of contemporary panic « in words which might be stereotyped as applicable to all similar occasions »:

\begin{abstract}
In all these speculations, only a small installment, seldom exceeding 5 per cent. was paid at first, so that a very moderate rise in the prices of the shares produced a large profit on the sum actually invested. This possibility of enormous profit, by risking a small sum, was a bait too tempting to be resisted; all the gambling propensities of human nature were constantly solicited into action; and crowds of individuals of every description the credulous and the suspicious, the crafty and the bold, the raw and the experienced, the intelligent and the ignorant, princes, nobles, politicians, placemen, patriots, lawyers, physicians, divines, philosophers, poets, intermingled with women of all ranks and degrees, spinsters, wives, and widows, hastened to venture some of their to venture some of their property in schemes of which scarcely anything was known but the name. (Lawson 1848, p. 3)
\end{abstract}

Credit and speculation figured prominently as the causes of the depression identified by the House of Lords secret committee on the causes of distress: «...those which are connected with the Extension of Commercial Speculation, encouraged or checked by the Facility, or the Difficulty, of obtaining Credit» (Secret Committee on Commercial Distress 1848a, p. iii). Emphasis on psychological contagion is found for instance in Langton 1857, John Stuart Mill 1826, (cited and discussed by Link 1959, p. 151), Longfield 1840 . Authors stressing the role of speculation are, for instance, Tooke (for a discussion see Link 1959, pp. 131, 133-5, 139-41, 145-7, 157), J. S. Mill (Link 1959, pp. 53-69, 149, 166-9, 171, 175, 177-8); Wilson (Link 1959, pp. 112, 114, 119-20, 124), Ganilh 1826, Anonymous (Raguet) 1829, Coquelin 1852, Wilson 1859, C. S. [Courcelle-Seneuil ?] 1860. Emphasis on speculation must have been quite popular at the time, as Guthrie refers in 1864 that «The favourite doctrine of the Times and its followers is, that the mania for speculation is a disease to which human nature is subject, and which can be removed or alleviated only by moral appliances» (Guthrie 1864, p. 5).

Juglar's belated shift of emphasis on prices also was not a novelty ${ }^{49}$. Besides the already cited Tooke ${ }^{50}$, and a number of characterizations of the state of distress as one of low or falling prices ${ }^{51}$, by the 1880 s we already had Jevons's statistical investigations, and a number of writings explicitly inquiring into the relationship of prices and fluctuations (for istance Giffen's «Trade Depression and Low Prices» (1885), an anonymous's «Depression of trade and prices of commodities » (1886), Leroy-Beaulieu's «La baisse des prix et la crise commerciale dans le monde » (1886), Foxwell's Irregularity of employment and fluctuations of prices (1886), and Marshall's «Remedies for fluctuations of general prices » (1887), Wasserrab's Preise und Krisen $\left.(1889)^{52}\right)$. Although a number of reflections on

49 As Niehans (1992, p. 552) conjectured, the relative ease of gathering statistics on prices rather than, e.g., production, surely favoured emphasising this factor (see footnote 24 above). One, however, should remember that a number of equilibrating mechanisms in Classical economics (and, later, also neoclassical economics) were based on prices (whether of goods or of capital), and there was therefore also a theoretical interest in examining this factor.

${ }^{50}$ We also have to mention the explicit reference to «The connection of the Currency with Prices» in Tooke 1844 .

${ }^{51}$ See e.g. Horsley Palmer's testimony before the Secret Committee on Commercial Distress (1848).

${ }^{52}$ For a survey, taking however Juglar as a starting point, see William 1919. 
prices took as a starting point their relationship to the quantity of money, suggestions as to the link between prices, credit and speculation could easily be found in the literature: Cobden, for instance, prefacing Chevalier's argument, wrote that «The tendency to a general rise of prices would lead to an expansion of credit, and an increase of speculation, which would be followed by panics and convulsions » (Cobden 1859, p. x).

The ingredients of Juglar's account of the cycle were thus not new at the time of his writing, and actually were rather commonplace. This, itself, is not to deny the originality of Juglar's specific combination of these elements, an assessment of which would be beyond the purpose of this paper, but only to point out that Juglar's later fame cannot have depended on the analytical components of his theory of crises.

\section{II.4. The medical metaphor: instability and the mysterious tendency to self-adjustment}

The use of medical metaphors to describe crises was quite widespread before and after the time of Juglar's writings, and the citation of a few instances may suffice. Apart from the unspecific references to one or another cause of crises as «a canker», «an internal ulcer» (Cory 1842, p. 3), as a «maladie» (Chevalier, before the Société d'Economie Politique, 1854, p. 430) or to the various occurrences of panics as a «melancholy list» (Evans 1859, p. 1), two at least were the connotations with which crises were compared to diseases. One related to the spreading and amplifying of disturbances. Longfield, for instance, wrote that the crisis « is like an epidemic [...], like the plague, or any other infectitious disease which may cease of itself» $(1840$, p. 222); similarly, Condy Raguet began an article on the «Principles of banking» with the following word: "When a community is in the full enjoyment of health, few persons are to be found willing to listen to the warning of the cautious; and it is not until the destroying epidemics appears, and when relief would come almost too late, that the public mind is in a state capable of receiving the truths, a previous acquaintance with which might have saved them from disease. What is true of physical evils, is equally true of the moral evils» $(1829$, p. 1$)$. Similarly Wade («The spirit of speculation is often epidemic»: 1833, p. 209) and Guthrie: «Physicians seek, with more or less success, to explain the recurrence of epidemics; and shall economists despair of accounting for the periodicity of this widespread frenzy?» $(1864$, p. 6). In such a usage, the emphasis is on the contagious character of crises. Although Juglar did not use this specific analogy in the first edition, while there is only a passing remark in the second («cette spéculation est contagieuse»: 1889, p. 166), it is interesting to record such occurrences in the literature for they indicates a belief that crises are the result of some kind of instability. Other analogies, of course, could and did do equally well, such as the suggestive «down go prices like an avalanche» (Williams 1857, p. 55).

The second connotation of the medical analogy is the comparison of crises to a disease, intended as an anomaly in the normal development of the economic system. We find it for instance in Say who, after listing «wars, embargoes, oppressive duties, the dangers and difficulties of transportation », social unreast, increasing uncertainty, arbitrary exactions, jobbing and speculation as causes of 
obstruction to circulation, added: «No sooner is the cause of this political disease removed, than the means of production feel a natural impulse towards the vacant channels, the replenishment of which restores activity to all the others. One kind of production would seldom out-strip every other, and its products be disproportionately cheapened, were production left entirely free »(Say 1803, cited from the 1880 translation of the 4th edition, Book 1, Chs. 15 and 16). J. A. Lawson wrote of commercial panics as «diseases to which the body politic is subject - not chronic diseases, but epidemics as regular in their recurrence as influenza itself, though only at longer intervals », and contrasted the regular natural function to the effects of «some interference either from the government or ourselves deranged the usual course of things » $(1848$, p. 2$)$. Roscher referred to crises as disturbances of equilibrium «belonging to the most dangerous shocks, diseases of the body of the economy, so to speak» $(1849$, p. 723$)$. Briaune opened his pamphlet remarking that «Le corps social est, comme le corps humain, sujet à des maladies dont les unes tiennent à des accidents extérieurs et n'apportent qu'un trouble momentané dans les fonctions vitales, tandis que les autres, causés par des vices organiques et passant à l'état chronique, influent sur la constitution et sur le développement des individus et des societés » (Briaune 1840, p. 1), commercial crises being of the second sort. These kinds of references to diseases clearly contrast the natural and healthy state of the system to the evil consequences of some disturbance, whether internal or external: the disease $i$ s the trouble.

The medical doctor in Juglar emerges again here: he - following his Paris mentors, as rightly pointed out by Frobert and Hamouda (2005) - interpreted the disease not as a functional damage, but rather as the consequence of such damage $^{53}$. While in the conception of Say, Briaune and Lawson the emphasis is on the lack of health, revealing a purely negative conception of crisis as a derangement of the natural state of the system, in Juglar there is also a positive connotation: the crisis and the subsequent liquidation play a specific role in the elimination of the excesses and abuses that give rise to the disease. Their role, like that of a disease, is to bring back to the equilibrium. Driven by an unspecified self-rightening tendency (the consequence of the absence of specification is the lack of an explanation of the trough of the cycle, especially in the first edition of Juglar's book), similar to the «force médicatrice de la nature», the crisis is

\begin{abstract}
une réaction salutaire de l'économie opposée à la maladie et en lutte contre ses mauvais résultats. Cette puissance qu'on désigne sous le nom de force médicatrice de la nature, est, comme l'antidote, à côté du poison; elle tend sans cesse à rétablir le calme et l'équilibre dans l'organisation. (Hardy 1849, p. 389)
\end{abstract}

Here is the sense of De Foville's recollection, according to which Juglar « is the only person I have ever heard praise the benefits of fever, and he once did it with such poetic eloquence that the passers-by stood still to listen » (1905, p. 293).

In this field, Juglar was better equipped that most other users of medical metaphors. While generally the analogy with a disease is only meant to emphasize that something wrong is going on in the economic system, preventing it from

\footnotetext{
${ }^{53}$ «La maladie n'est pas la lésion elle-même, elle est plutôt la suite, le retentissement vital de cette lésion» (Hardy 1849, p. 388).
} 
working normally, in the case of Juglar the metaphor is likely to have played a heuristic role, as pointed out by Frobert and Hamouda (2005). This is not an isolated case: sometimes metaphors are only used to illustrate an argument, but often they help transferring a way of thinking from one domain to another. The history of business cycle theory offers other examples, such as the waves of the ocean (suggesting gravitation around a 'mean sun') ${ }^{54}$ or the pendulum - the metaphor that eventually displaced references to the physiology of the system to emphasize its mechanics ${ }^{55}$ : the choice of the analogy, whether for illustrative purposes or as a heuristic device, is never neutral.

\title{
II.5. Crises and progress
}

Juglar's idea that crises are painful but unavoidable and necessary to growth was also not new at the time he formulated it. It was clearly expounded for instance in Garnier's entry on "Commercial crises» in the Dictionnaire universel théorique et pratique du commerce et de la navigation. He maintained that commercial crises are inevitable, «tiennent à la nature des choses » rather than being due to exogenous factors, but are temporary and necessary to permit growth, being the outcome of the «overexcitement of entrepreneurial spirit»:

\begin{abstract}
Elles sont inévitables; mais les inconvénients ne peuvent, à beaucoup près, balancer les immenses avantages que leur peuples retirent des développements immenses de leurs affaires. Les crises de cette nature [les crises commerciales] son des crises de croissance; et mieux vaut l'activité et la richesse avec les crises commerciales (celles-ci dussent-elle être dans la nature permanente des choses) que l'inaction et la pauvreté. Les pays riches et prospères sont quelque fois en crise; les pays pauvres y sont d'une manière permanente.

Au surplus, les crises commerciales sont passagères de leur nature. Les baisses soudaines dans la valeur des choses amènent des acheteurs, facilitent la consommation, font cesser l'engorgement et provoquent la liquidation des affaires mal engagées. Dans ces évolutions, les producteurs ou les détenteurs de marchandises ont perdu; mais les acheteurs ou détenteurs de capitaux circulant ont gagné; certaines fortunes particulières ont été détruites, d'autres se sont élevées; il y a eu des souffrances individuelles, mais, au point de vue social, il n'y a pas le même appauvrissement, et l'inconvénient de la crise est racheté par la disparition des entreprises véreuses. C'est ainsi qu'après un temps assez limité on voit souvent, après la crise, les affaires reprendre avec plus de vigueur et plus d'activité que jamais. (Garnier 1859, p. 925).
\end{abstract}

$\mathrm{R}$. Hare, in «an effort to refute the opinion, that no addition is made to the capital of a community by banking», admitted that «the facility of getting credit, by multiplying purchasers», may contribute towards "great elevations and depressions in the prices of real estate», making people «alternatively rich or poor, according as greater or less confidence exists with respect to our national prosperity, and the consequent prospective demand for farms, plantations, or building lots, increases or diminished». But maintained that

Judging from experience, it may be a question whether the ultimate, or average accumulation of national wealth, is less in consequence of the fluctuations of prices to which I

\footnotetext{
${ }^{54}$ See footnote 39 .

55 On the pendulum metaphor see Louçã, 2001.
} 


\begin{abstract}
have alluded. Such fluctuations rouse men to extraordinary exertion, and by a reaction after each subsiding wave, cause business to revive with a renovated and accumulated force. It is in consequence of the stimulus and reaction which accompany or follow great catastrophes, such as are produced by floods or fires, that after a few years, communities which have been subjected to them, will appear to have made advance even greater than might have been anticipated, had no such deteriorating accident occurred (Hare 1852, pp. $705-6)^{56}$.
\end{abstract}

This view was not isolated. In 1864 Ferrara pointed out that the linkage between credit and crises induced many («quest'ultima opinione è oggi assai divulgata»), «enamored with the industrial miracles credit permits to make real», to accept crises as the price of growth. Besides Garnier's entry, he also referred to Coquelin (without giving a precise reference), and explicitly interpreted Juglar's statement that the return of crises is a condition of progress in industry as belonging to this tradition (Ferrara 1864, p. 274) ${ }^{57}$. Juglar himself referred to Overstone in this respect (1889, p. 6 ; see section I.2), and Langton 1857 also deserves a place in this connection (for a discussion see Ashton 1934, pp. 71-2).

\title{
II.6. Proximate causes and vera causa of crises
}

Although Juglar's distinction between 'determining' or 'occasional' cause and 'predisposition' was rooted in the medical approach with which he became acquainted in Paris, an analogous distinction using different terms was available on the other side of the Channel, and it is not surprising that some authors applied it to the return of crises precisely in the same way as Juglar did, that is, both for its methodological implications and as a rhetorical device.

A very similar approach was uses as early as 1840 by Briaune, followed by Isaac Preston Cory (1842), James Anthony Lawson (1848, 1848a and 1848b - the latter of which Juglar may have read, as it was published in one of the sources acknowledged in the scanty bibliography appended to Juglar 1863), Charles Coquelin (1852), John Mills (1868) and Stanley Jevons (1878). The frequent recurrence of this kind of argument witnesses that these authors felt the same kind of urge as Juglar, and perceived the crises problem essentially in the same way. The periodic return of crises suggested to these writers that the causality principle, that similar effects must have the same cause, ought to substitute the search for individual causes of crises as a principle of explanation. Juglar's approach was thus not original (although his rhetorics gave more strength to his critical remarks that the authors were capable of doing, Jevons excepted), but places him among the authors struggling to reject the mainstream interpretation of crises as essentially accidental phenomena, non connected to each other.

${ }^{56}$ According to Schumpeter, Hare «was one of the earliest of the few writers who attributed to cycles the function of speeding up economic advance» (Schumpeter 1854, p. 743n). Schumpeter's opinion on the scarcity of such writers contrasts with Ferrara's.

${ }^{57}$ Ferrara referred to Juglar rather diminishingly, but recognising the impact of his book, as « uno scrittore, autore di un'operetta che molto eccitò l'attenzione degli Economisti e scritta di proposito per provare con ricca copia di cifre la periodicità delle crisi, le chiama soventi, in un linguaggio che mi permetterò di trovare un poco troppo cinico, semplici liquidazioni; ed il loro frequente ritorno sarebbe, secondo lui, «una delle condizioni, a cui è vincolato il progresso della grande industria» (1864, p. 274). 


\title{
II.7. Equilibrium
}

Not only Juglar's statements must be discussed, but also at least one of his omissions. Among the problems Juglar was not aware of, the most important is the failure to discuss the equilibrium conditions. Its relevance is twofold. Historically, one of the main theoretical problems to be solved in studies on crises and cycles has been the relationship of economic distress to equilibrium. It was generally accepted, from the gluts debate at least to interwar years that crises are disequilibrium situations, and one had to reconcile this fact with theoretical approaches describing economic systems as tending towards equilibrium. The mainstream approaches have tried to interpret cycles and crises as partial and temporary exceptions to the theoretical norm, due to frictions, exogenous events, miscalculations, mismanagement or some other impediment or accident. The critics, on the contrary, rejected the idea that the system is self-equilibrating and either introduced some form of systematic instability or suggested to switch altogether to a different theoretical set-up (e.g., a dynamic one $)^{58}$. At Juglar's time, the debate concerned the validity of Say's Law: those who accepted it only conceived of partial overproductions, interpreted as accidental and temporary sectorial maladjustments that solve on their own, while the critics either rejected the law altogether, or tried to imagine some exceptions to its working. It may appear odd that Juglar never referred to Say's Law, but in reality this is consistent with Juglar's omission to tackle the equilibrium problem.

The second reason why this omission is important regards the logic itself of Juglar's argument: having failed to characterize equilibrium and its properties, Juglar could only assume as a matter of course - but in reality left unexplained the transition from liquidation to recovery. Needless to say, this is a major gap in the construction of a theory on the cycle. Such a step, of course, was not easy at the time of Juglar's writing: for a rigorous formulation we have to wait for Marx's schemes of expanded reproduction. Juglar, however, did not even realise that such a step was necessary to the task he set himself of accounting for the succession of states. James Wilson, is spite of not having been able to solve the problem, clearly saw this was a necessary step to be taken:

\begin{abstract}
In order to go into the investigation proposed, it is obvious that we must discover, that we must condescend to some given sum which, could it be maintained steadily, would be the correct amount of the means of the country absorbed for this particular purpose annually, namely, the purchase of wheat (Wilson 1840, p. 19).
\end{abstract}

Wilson admitted he knew of no principle to determine this point, and as a first approximation he took the average price of corn, in analogy with the symmetrical movement of a pendulum fluctuating around it middle point. He took, however, as its starting point, by imagining a given distribution of the capital of the country among various sectors bearing «the exactly proper proportion of to each other to supply the wants of the community » (p.21), and examined the consequences of a shortage of wheat throughout the system ${ }^{59}$.

${ }^{58}$ For a discussion see Besomi 2006.

${ }^{59}$ For a discussion of Wilson's work on fluctuations see Link 1959 (on this issue, see in particular pp. 108-14). 
More elaborate is John Mills's argument. While Juglar swiftly avoided discussing the relationship of cycles and equilibrium, Mills precisely saw that there lied the main theoretical problem. Mills, as well as Juglar, considered prosperity the 'healthiest' phase of the cycle (1868, p. 24) and attributed to credit a «normal tendency to grow» (p. 32) and a «normal rate of growth». Mills also left this tendency unexplained, assumed as a matter of fact, but specified that credit «can only grow under the stringent condition of paying a discount proportioned to the degree in which growth outruns the supply of loan capital» (p. 32). Credit has thus a price, and this price is subject to the «economic law of supply and demand», «tending to preserve the necessary equilibrium» between credit and capital. "I say 'the necessary equilibrium' because, in fact, Credit cannot long exist without it. Belief is founded upon evidence, and must be kept in contact with it» (p. 31). The growth of credit is thus kept in check by the stabilizing forces acting upon the rate of interest, yet it is also subject to the destabilizing effect of speculation fostered by excesses of confidence (p. 27 and passim). Instability is thus limited by the stabilizing force (which sums its effects ${ }^{60}$ to, and «applies an effective break to[,] the dangerous velocity with which a too facile Credit would multiply transactions» and «tends to preserve the natural and [...] that vitally important equipoise between the growth of bill-making Credit, and the supply of Capital from accumulated profits and savings »: p. 32). But in the speculative stage of the cycle, credit

\begin{abstract}
grows under such stimulating conditions, that any weighting of that side of the scale is quite out of question. The time comes too soon when our two laws, while they continue to be correlative, tend to become less and less coefficient. The adjusting principle is still at work, but under the influences now gathering, it becomes by degrees overborne, and at last overwhelmed. The Credit end of the beam is too far depressed to be raised again until lightened of its load by a violent process. As this, however, is owing to the relative default of Capital, it is clear that no amount of paper promises, now placed in the opposite scale, would redress the balance (p. 35).
\end{abstract}

In such conditions, the set of psychological factors affecting credit «either neutralises the economic law of demand, or, reversing the poles of the magnet, it exerts a repellant instead of an attractive influence» (p. 34). After the panic, the law of supply and demand cannot immediately exert its effect for, while gold and notes (after some caution on the part of lenders) flow back into the bank, borrowers do not find motive to invest, in spite of being «tempted by a low rate of interest », due to the restrictions in purchasing power (and therefore in demand) felt by most people as an effect of the crisis (pp. 20-22). But slowly confidence will return, and will find good conditions in the "great accumulation of unused Capital and the ruling of an excessively low rate of interest $»$ that established in the postpanic period, and bring back to the normal time of revival, where credit continues to grow in an healthy fashion, kept in check by the law of supply and demand (pp. 22-24).

The contrast with Juglar is striking. Mills has clearly understood that the problem of crises cannot be severed from reflections on their relationship to equi-

${ }^{60}$ «We have, in fact, one of those cases to which the axiom of Mr. Mill is applicable, - 'the joint effect of causes is the sum of their separate effects'» (Mills 1868, p. 32). 
librium. In Juglar, by contrast, we only find the assumption that, by simple elimination of the excesses, the crisis will bring the system back to a state of stable (momentarily, at least) equilibrium. Juglar did not feel the need to discuss why such an equilibrium acts as an attractor to the system, while most of his contemporaries were discussing the aspects of this problem in the context of Say's law and later the problem was clearly perceived to be at the heart of trade cycle theorizing.

\section{CONCLUSION: JUGLAR'S PLACE IN THE TRANSITION FROM CRISES TO CYCLES THEORIES}

The partial survey of the state of crisis theories at around Juglar's time has shown that scarcely any of the ingredients of his approach were new. They were instead all widely discussed in the literature dealing with these phenomena, sometimes even held as commonplace. Long before Juglar published the first edition of his book, several of the ideas it contains had already circulated among writers interested in economic disturbances: that crises recur with some approximate regularity, following a recurrent path of succession of recognizable phases, and that they do play a necessary and helpful (albeit painful) part in the process of economic advance, to be explained in terms of the internal dynamics of the system rather than by reference to external events. These views were subject to further discussion by the time the second edition of Juglar's book appeared almost three decades later.

If claims such as Schumpeter's as to Juglar's merits are clearly hyperbolic, Juglar's contribution was important. In the first place, Juglar compiled in a single book a wealth of arguments that were previously scattered in publications of a temporary nature (pamphlets, which probably circulated widely at the time but are now difficult to find even in important libraries) or in non-professional journals devoted to a number of arguments, or in financial and commercial publications. Secondly, as several commentators have noticed, Juglar was the first to base his conclusions on thorough statistical investigations (albeit of a rather naïve kind).

I see, however, his most important contribution in the explicit setting of some of the problems of business cycle theory: in particular, the necessity of identifying causal links between successive phases. The same problems were indeed discussed by others before him, and some had even provided better articulated and more complete answers than he did, but had not always expounded the problem as clearly as Juglar. He began his treatment with a discussion of the epistemic requisite for a good theory (see section II.6), and carefully laid the principle that the explanation of the recurrence of crises should be based on the chaining of the different phases of the cycle. He was not himself capable of solving this problem, but he has the merit of having clearly posed it. This was a fundamental step for the development of the first theories of crises, concerned with the causes of each individual instance, into theories of recurring crises, concerned instead with crises as a class of related phenomena. These, in turn, later evolved into the modern theories of business cycle to which, in this sense at least, Juglar gave an important contribution by channeling the efforts of a multitude of writers in the right direction. 
Juglar's epistemic suggestion was only silently incorporated in his successor's theoretical apparatuses. His explicit influence (in terms of citations) did not very much extend beyond France, and even there Juglar was only paid a formal tribute by true theorists, who tackled the problem in the terms of the requirements of current theory. This is precisely the limit of Juglar's contribution: by lacking a specific theoretical perspective and having renounced dealing with the main theoretical problem concerning crises, namely their relationship to equilibrium, he could not be influential except on some marginal points (such as the definition of 'crisis', which for a while was discussed) and by further spreading, refining and supporting the very broad - but already commonplace - picture.

\section{REFERENCES}

Académie des Sciences Morales et Politiques [Prix Bordin. Section d'économie politique et statistique], Académie des Sciences Morales et Politiques, Séances et Travaux, 1860, p. 186.

Anonymous, «Commercial distress of the country», Edinburgh Review, XXVII, December, 1816, pp. 373-91.

Anonymous [R. McCulloch], «Commercial Revulsions», Edinburgh Review XLIV, 1826, June, pp. 70-93.

Anonymous [Malthus], «[Review of] Thoughts and Details on the High and Low Prices of the last Thrity Years, by Thomas Tooke», Quarterly Review XXIX, 1826, April, pp. 214-39.

Anonymous (Condy Raguet?), [Untitled report from «Philadelphia, May 9, 1829»], The Free Trade Advocate and Journal of Political Economy 1: 9, 9 1829, May, pp. 303-4.

Anonymous ['A Political Economist'], «Alleged commercial decades or cycles», The Economist, 19 November and 24 December, 1864, pp. 1428-9. and 1577-8.

Anonymous, «Depression of trade and prices of commodities», Bankers' Magazine (London) XLVI, 1886, June, pp. 465-71.

Arnon A., Thomas Tooke: Pioneer on monetary theory, 1991, Aldershot: Elgar.

Ashton T. S., Economic and social investigations in Manchester, 1833-1933: A centenary history of the Manchester Statistical Society, London: King [cited from the reprint by The Harvester Press, Hassocks, 1977], 1934.

Bagehot W., Lombard Street : A Description of the Money Market, London: King, 1873.

Balfour D. M., «The present commercial crisis», Hunt's Merchant Magazine XVIII, May, 1848.

Balfour T. G., «Opening address» Journal of the Royal Statistical Society, 52: 4, December, 1889, pp. 517-34.

Bell G., M.«History of English Panics», Hunt's Merchant Magazine, XXIII:VI, December, 1850, pp. 604-10.

von Bergmann E., Die Wirtschaftskrisen: Geschichte der nationalökonomischen Krisentheorien, Stuttgart: W. Kohlhammer, 1895.

Besomi D., «Tendency to equilibrium, the possibility of crisis, and the history of business cycle theories», History of Economic Ideas XIV: 2, 2006, pp. 53-104.

Besomi D., «'Marxism gone mad': Tugan-Baranovsky on crises, their possibility and periodicity», Review of Political Economy 18:2, April, 2006a, pp. 1-25.

Besomi D., «John Wade on the commercial cycle: An early endogenous dynamic model», forthcoming in European Journal of the History of Economic Thought 15:4, 2008, December.

Bonnet V., Questions économiques et financières à propos des crises, Paris: Guillaumin, 1859.

Bonnet V., «Enquête sur le crédit et la crise de 1863-64 », Revue des Deux Mondes, 15 November and 1 December 1865 (reprinted: Paris, Guillaumin, 1866). 
Briaune M., Des crises commerciales. De leurs causes et de leur remèdes, Paris: Bouchard-Huzard 1840 (reprinted New York: Burt Franklin, 1971).

Chitti L., Des crises financières et de le réforme du système monétaire, Bruxelles: Meline, 1839.

Clarke H., «On the mathematical law of the cycle», The Railway Magazine and the Annals of Science V, November, 1838, pp. 378-80.

Clarke H., «Physical economy - A preliminary inquiry into the physical laws governing the periods of famine and panic», Railway Register (reprinted in F. Louca,-Francisco and J. Reijnders, eds., The foundations of long wave theory: Models and methodology. Volume 1. 1847, (Cheltenham: Elgar, 1999).

Clément A., «Des crises commerciales », Journal des Economistes XVII, February, 1858, pp. 161-91.

Cobden R., «Translator's Preface» to M. Chevalier, On th Probable Fall in the Value of Gold, the Commercial and Social Consequences which May Ensue, and the Measures which it invites, Manchester: Alexr. Ireland; London: Smith; Edinburgh: Black, 1859.

Collison Black R. D., «Dr. Kondratieff and Mr. Hyde Clarke», Research in the History of Economic Thought and Methodology 9, 1992, pp. 35-58.

Coquelin C., «Les Crises Commerciales et la Liberté des Banques », Revue des Deux Mondes XXVI, 1 November, 1848, pp. 445-70. Abridged as Coquelin 1850.

Coquelin C., «The causes of commercial crises «, Hunt's Merchants' Magazine XXI, October, 1849, pp. 371-88.

Coquelin C., «Restrictions on banking the cause of commercial crises », Bankers' Magazine X, 1850, pp. 219-27 and 308-13.

Coquelin C., «Crises Commerciales», Dictionnaire de l'Economie Politique, ed. by Ch. Coquelin et Guillaumin, Paris: Guillaumin, 1852.

Coquelin C., «Crédit», Dictionnaire de l'Economie Politique, ed. by Ch. Coquelin et Guillaumin, Paris: Guillaumin, 1852a.

Cory I. P., Competition: its abuse one of the chief causes of the present distress among the trading, manufacturing, and commercial classes: with suggestions for remedying it, London: Painter, 1842.

Courcelle-Seneuil J. G., Traité théorique et pratique d'économie politique, Paris: Amyot, 1858.

C. S. [Courcelle-Seneuil ?], «Crise», in Garnier-Pagès (ed.), Dictionnaire politique : encyclopédie du langage et de la science politique, Paris: E. Duclerc et Pagnerre, 1860.

De Foville A., «Clément Juglar», Economic Journal 15, June, 1905, pp. 293-8.

De Molinari G., «La Crise financière et commerciale en Engleterre », Journal des Econonomistes $1^{\text {ère }}$ série, XVII, Juin, 1847, pp. 274-84

England M. T., «Economic Crises», Journal of Political Economy 21: 4, April, 1913, pp. 345-54.

Evans D. M., The history of commercial crises, 1857-58 and the stock exchange panic of 1859, London: Groombridge (New York: Kelly, 1969), 1859.

Ferrara F., «Delle crisi economiche», Preface to vol. IV of Biblioteca dell'Economista (second series); 1864 as reprinted in Esame storico-critico di economisti e dottrine economiche del secolo XVIIIe prima metà del XIX. Raccolta delle prefazioni dettate dal ProfessoreFrancesco Ferrara, vol. 2, Torino: UTET, 1890.

Foxwell H. S., «Appendix on the Theory of Cycles» to Jevons 1884, 1884, pp. 361-2.

Foxwell H. S., Irregularity of employment and fluctuations of prices, Edinburgh: Co-operative Printing Company, 1886.

Frobert L., and Hamouda O., «L'influence de l'école anatomo-clinique sur la première 'vision' du cycle économique chez Clément Juglar 1846-1862», paper presented at the IX ESHET conference, Stirling, June 2005.

Garnier J., Elements de l'économie politique. Exposé des notions fondamentales de cette science et de l'organisation économique de la société, 1845, Paris: Garnier/Guillaumin (3rd ed., 1856).

Garnier J., «Crises commerciales », Dictionnaire universel théorique et pratique du commerce et de la navigation, Paris: Guillaumin, 1859 
Giffen R., «Trade Depression and Low Prices », Contemporary Review XLVII, June, 1885, pp. 80022.

Groenewegen P., «Joseph Clément Juglar (1819-1905): From Physician to Analyst of Business Cycles », in P. Groenewegen (ed.), Physicians and Political Economy. Six Studies of the Work of Doctor-Economists, London and New York: Routledge, 2001.

Guthrie W., «Introduction» to G. Guthrie, Bank Monopoly the Cause of Commercial Crises, Edinburgh: Blackwood, 1864.

Hardy A., «Maladie», in J.-P. Beaude, Dictionnaire de Médicine Usuelle, Paris : Didier, 1849.

Hare R., «Do banks increase loanable capital?», Hunt's Merchant's Magazine XXVI: VI, June, 1852, pp. 702-6.

Henderson J. P., «Astronomy, Astrology, and Business Cycles: Hyde Clarke's Contribution», Research in the History of Economic Thought and Methodology 9, 1992, pp. 1-34.

Hutchison T. W., A Review of Economic Doctrines 1870-1929, Oxford: Clarendon Press, 1953.

Jevons W. S., «Commercial crises and sun-spots», Pt. 1, Nature, vol. XIX, 14 November, pp. 33-37. 1878, reprinted in Jevons 1884, pp. 221-35.

Jevons W. S., Investigations in currency and finance, ed. by H. S. Foxwell, London: Macmillan, 1884.

Joplin W., A letter on fluctuations in the money market chiefly with the view of explaining the nature of those violent pressures termed panics, addressed to the Bank of England, London: Hamilton, Adams \& Co (2nd ed.), 1854.

Juglar C., «De la population en France de 1725 à nos jours (1849)» Journal des Economistes 31: 129 , 15 Janvier, pp. 75-80, and vol. 32: 133-134, May-June 1852, pp. 54-77.

Juglar C., «Des crises commerciales et monétaires de 1800 à 1857 », Journal des Economistes, XIV, April and May, 1857, pp. 35-60 and 255-67.

Juglar C., «Situation comparée de la Banque de France et de la Banque d'Angleterre d'après les comptes rendus officiels pendant les crises commerciales depuis 1799», Journal des Economistes, Tome 16, $2^{\mathrm{e}}$ Série, $4^{\mathrm{e}}$ Année, No. 47 du 15.12.1857, pp. 262-265

Juglar C., Des Crises Commerciales et de leur retour périodique en France, an Angleterre et aux Etats-Unis, Paris: Guillaumin, 1862.

Juglar C., «Crises Commerciales», in M Block, Dictionnaire général de la Politique, Strasbourg: Berger-Levrault (cited from the reprint: Strasburg: Imprimerie de Veuve Berger-Levrault, 1863).

Juglar C., «Tableaux graphiques des crises commerciales et de leurs retours périodiques d'après les bilans de la Banque de France », Académie des Sciences Morales et Politiques, Séances et travaux n.s.: 17, January-June. Offprint: Paris: Piccard, 1882.

Juglar C., Des Crises Commerciales et de leur retour périodique en France, en Angleterre et aux Etats-Unis, 1889, 2nd edition, Paris: Alcan (Reprinted New York: Kelly, 1967).

Juglar C., «Crises commerciales», Nouveau Dictionnaire d'Economie Politique, de L. Say and J. Chailley. Paris: Guillaumin, 1891.

Juglar C., A Brief History of Panics and their Periodical Occurrence in the United States. Ed. by DeCourcy W. Thom, New York, 1893: Ptnam (2nd ed. 1897, 3rd. ed. 1916. The latter reprinted by Kelly, New York, 1966, 1989, and Burlington: Fraser, 1993).

Juglar C., «Les crises commerciales et financières et les crises économiques générales », Paris: Imprimerie Paul Dupont, 1900.

Juglar C., «Crises commerciales», Nouveau Dictionnaire d'Economie Politique, de L. Say and J. Chailley. Paris: Guillaumin (2nd edition), 1900a, pp. 641-651.

Juglar C. et P. des Essars, «Crises financières et commerciales», Dictionnaire des Finances, ed. by L. Say, Paris-Nancy: Berger-levrault, 1889, pp. 1348-55.

Lagasquie A., «Causes», in J.-P. Beaude, Dictionnaire de Médicine Usuelle, Paris: Didier, p. 313, 1849.

Langton W., «Observations on a table shewing the balance of accounts between the mercantile public and the Bank of England», Transactions of the Manchester Statistical Society, Session 1857-58, 1857,pp. 9-22. 
Lawson J. A., On commercial panics : a paper read before the Dublin Statistical Society, Dublin, 1848 .

Lawson J. A., «The Cause of Commercial Panics», Bankers' Magazine (London) VIII, 1848a, pp. $415-20$

Lawson J. A., «The Cause of Commercial Panics », Hunt's Merchants' Magazine XIX, 1848b, p. 282.

Leroy-Beaulieu P., «La Baisse des Prix et la Crise Commerciale dans le Monde; Causes Alléguées, remèdes proposés », Revue des Deux Mondes, 1886, LVI:3, 15 May, 1886, pp. 383-418.

Lescure J., Des crises génerales et périodiques de surproduction, Paris: Domat-Montchrestien (4th ed. Paris, 1932), 1907.

Longfield S. M., «Banking and currency», Dublin University Magazine 15, pp. 1-15, 218-33; 16 , 1840, pp. 371-89, 611-20.

Louçã F., «Intriguing pendula: founding metaphors in the analysis of economic fluctuations », Cambridge Journal of Economics, 25, January, 2001, pp. 25-55

Macleod H. D., «Crisis, commercial», in Dictionary of Political Economy: Biographical, Bibliographical, Historical, and Practical, London: Longmans, 1863.

Marcy G., "La théorie des crises chez les socialistes français au XIX ${ }^{\mathrm{e}}$ siècle», in Mélanges économiques dédiés à M. le Professeur Gonnard, Paris : Librairie Générale de Droit et de Jurisprudence, 1946, pp. 261-74.

Marshall A., «Remedies for fluctuations of general prices », Contemporary Review, March 1887 (eprinted in Memorials of Alfred Marshall, London: Macmillan, 1925, pp. 188-211).

Members of the New York Press A Brief Popular Account of All Financial Panics and Commercial Revulsions in the United States from 1690 to 1857, New York: Haney, 1857.

Mill J. S., «Paper currency and commercial distress», in J. St. Mill, Collected Works, edited by J. M. Robson, vol. IV, Toronto: University of Toronto Press, 1826 and London: Routledge, 1967, pp. 71-123.

Mills J., «On credit cycles and the origin of commercial panics», Transactions of the Manchester Statistical Society, Session 1867-68, 1868, pp. 5-40.

Miller H. E., Banking theories in the United States before 1860, Cambridge: Harvard University Press, 1927.

Morgan M. S., The history of econometric ideas, Cambridge: Cambridge University Press, 1990.

Niehans J., «Juglar's Credit Cycles», History of Political Economy 24(3), Fall, 1992, pp. 545-69.

Overstone (Loyd, S. J.), Reflections suggested by a perusal of Mr. John Palmer's pamphlet on the causes and consequences of the pressure on the money market, London, 1837.

Pellissier D., «Clément Juglar: héritage et actualité de sa théorie des cycles», Les traditions économiques françaises 1848-1939, ed. par P. Dockès, L. Frobert, G. Klotz, J. P. Poitier et A. Tiran, CNRS éditions, Paris, 2000, pp. 273-85.

Persons W. M., «Theories of Business Fluctuations», The Quarterly Journal of Economics 41: 1, November, 1926, pp. 94-128.

Petty W., Treatise of taxes \& contributions, London. In C. H. Hull, The economic writings of Sir William Petty, Cambridge: Cambridge University Press, 1662 (1899).

Raguet C., «On the principles of banking», Free Trade Advocate II :1, 4 July, 1829, pp. 1-8.

Rantoul, [Speech in the Massachussetts House of Representatives, 22 March, 1836]

Rey J. A., Les Crises et le Crédit, Paris: Guillaumin, 1862.

Robertson D. H., A study of industrial fluctuations. An enquiry into the character and causes of the socalled cyclical movement of trade, London: King, 1915.

Roscher W., «Die Produktionkrisen mit besonderer Rücksicht auf die letzten Jahrzehn», Die Gegenwart. Eine Encyclopädische Darstellung der neuesten Zeitgeschichte für alle Stände, vol. 3, Leipzig: Brockhaus, 1849, pp. 721-58.

Say H., «La Crise Financière et la Banque de France», Journal des Econonomistes XVI, January, 1847, pp. 193-207. 
Say J.-B., Traité d'économie politique ou Simple exposition de la manière dont se forment, se distribuent et se consomment les richesses, Paris: De Chapelet, 1803.

Schumpeter J. A., History of Economic Analysis, London: Allen \& Unwin, 1954.

Secret Committee on Commercial Distress, First Report from the Secret Committee on Commercial Distress; with the minutes of Evidence, London: House of Commons, 8 June 1848

Secret Committee on Commercial Distress, Report from the Secret Committee of the House of Lords appointed to inquire into the Causes of the Distress which has for some Time prevailed among the Commercial Classes, and how far it has been affected by the Laws for regulating the issue of Bank Notes payable on Demand, London: House of Commons, 28 July 1848, 1848a.

Société d'Economie Politique, «Influence des banques sur l'entrainement des capitaux et sur les crises. Réunion du 6 juin 1854 », Journal des Economistes, $2^{\mathrm{e}}$ série, vol. 11, June, 1854, pp. 42932.

Société d'Economie Politique, «Origine et causes de la crise actuelle. Réunion du 5 décembre 1857 », Journal des Economistes, ${ }^{\mathrm{e}}$ Série, vol. 16, December, 1857, pp. 465-73.

Spiethoff A., «Krisen», in Handwörterbuch der Staatswissenschaften, 4th ed., Jena (partial English translation as «Business cycles », International Economic Papers 3, pp. 75-171, with a new introduction, omitting parts of Pt. IV and the whole of Pt. V), 1925.

Tooke T., Thoughts and details on the high and low prices of the last thirty years, London: Murray, 1823 .

Tooke T., A history of prices and of the state of the circulation from 1792 to 1856, London: Longman (volumes 5 and 6 in collaboration with William Newmarch), 1838-57.

Tooke T., An inquiry into the currency principle; The connection of the Currency with Prices and the expediency of a separation of issue from banking, London: Longman etc. 1844 (Reprinted Routledge/Thoemmes Press, 1996).

Tugan-Baranowsky M. I., Les crises industrielles en Angleterre, Paris: Giard \& Brière, 1913.

Wade J., History of the middle and working classes, London 1833 (2nd ed.: London, 1834).

Walker A. - Stansfield, H., «Monetary panics. Correspondence between Hon Amasa Walker, of Massachussets, and Homer Stansfield, Esq., of Burley, England », Bankers' Magazine (New York) New Series XIV:7, January, 1860, pp. 497-509

Wasserrab K., Preise und Krisen, Stuttgard: Gottaschen, 1889.

Wells A. D., Recent economic changes, and their effect on the production and distribution of wealth and the well-being of society, New York, D. Appleton and Company, 1889.

Williams J. H., «The role of prices in the business cycle», Review of Economic Statistics 1:2, 1919, pp. 206-10.

Williams T. H., «Observations on Money, Credit, and Panics», Transactions of the Manchester Statistical Society, Session 1857-58, 1858, pp. 49-66.

Wilson J., Influences of the Corn Laws as affecting all classes of the community and particularly the landed interests, London, 1839.

Wilson J., Fluctuations of currency, commerce, and manufactures; referable to the Corn Laws, London, 1840.

Wilson J., Capital, currency and banking; being a collection of a series of articles published in the 'Economist' in 1845, on the principles of the Bank Act of 1844, and in 1847, on the recent monetary and commercial crisis ; ... London: AIRD (Economist), 1859.

Wirth M., Geschichte der Handelskrisen, Frankfurt a.m.: Sauerländer, 1858. 